Review

\title{
Nopal Cactus (Opuntia ficus-indica) as a Source of Bioactive Compounds for Nutrition, Health and Disease
}

\author{
Karym El-Mostafa ${ }^{1,2, \dagger}$, Youssef El Kharrassi ${ }^{1,2, \dagger}$, Asmaa Badreddine ${ }^{1,2}$, Pierre Andreoletti ${ }^{1}$, \\ Joseph Vamecq ${ }^{3}$, M'Hammed Saïd El Kebbaj ${ }^{4}$, Norbert Latruffe ${ }^{1}$, Gérard Lizard ${ }^{\mathbf{5}}$, \\ Boubker Nasser ${ }^{2}$ and Mustapha Cherkaoui-Malki ${ }^{1, *}$ \\ 1 Laboratoire Bio-PeroxIL, EA7270 University of Bourgogne, 6 Bd Gabriel, Dijon F-21000, France \\ 2 Laboratoire de Biochimie et Neurosciences, Faculté des Sciences et Techniques, Université Hassan I, \\ BP 577, Settat 26 000, Morocco \\ 3 Inserm and HMNO, CBP, CHRU Lille, Lille 59037, France \\ 4 Laboratoire de recherche sur les Lipoprotéines et l'Athérosclérose, Faculté des Sciences Ben M'sik, \\ Avenue Cdt Driss El Harti BP. 7955, Université Hassan II-Mohammedia-Casablanca, \\ Casablanca 20 000, Morocco \\ 5 Inserm and Laboratoire Bio-PeroxIL, EA7270 University of Bourgogne, 6 Bd Gabriel, \\ Dijon F-21000, France
}

$\dagger$ These authors contributed equally to this work.

* Author to whom correspondence should be addressed; E-Mail: malki@u-bourgogne.fr; Tel.: +33-380-396-205.

Received: 10 July 2014; in revised form: 4 September 2014 / Accepted: 8 September 2014 / Published: 17 September 2014

\begin{abstract}
Opuntia ficus-indica, commonly referred to as prickly pear or nopal cactus, is a dicotyledonous angiosperm plant. It belongs to the Cactaceae family and is characterized by its remarkable adaptation to arid and semi-arid climates in tropical and subtropical regions of the globe. In the last decade, compelling evidence for the nutritional and health benefit potential of this cactus has been provided by academic scientists and private companies. Notably, its rich composition in polyphenols, vitamins, polyunsaturated fatty acids and amino acids has been highlighted through the use of a large panel of extraction methods. The identified natural cactus compounds and derivatives were shown to be endowed with biologically relevant activities including anti-inflammatory, antioxidant, hypoglycemic, antimicrobial and neuroprotective properties. The present review is aimed at stressing the major classes of cactus components and their medical interest through
\end{abstract}


emphasis on some of their biological effects, particularly those having the most promising expected health benefit and therapeutic impacts.

Keywords: anti-inflammatory; antioxidants; cell signaling; Opuntia ficus-indica; polyphenols

\section{Introduction}

Opuntia ficus-indica (L.) Mill., commonly called prickly pear or nopal cactus, belongs to the dicotyledonous angiosperm Cactaceae family, a family that includes about 1500 species of cactus. $O$. ficus indica is a tropical and subtropical plant. It can grow in arid and semi-arid climates with a geographical distribution encompassing Mexico, Latin America, South Africa and Mediterranean countries [1]. Because the oldest Arabic medicine treatises do not mention cactus, it is generally accepted that Spain might have introduced the nopal fig tree in the 15th century from Central America after the conquest of the northwest of Africa.

Nowadays, local populations in Morocco distinguish three varieties of $O$. ficus indica. The first, with prickly cladodes, is called "Christians' nopal" and is commonly used as a field fence. The second, with inermis cladodes, is "Muslims' nopal" and serves as a green fodder for cattle. The last variety, with large inermis cladodes, is referred to as "Moses' nopal", grows essentially in the south of Morocco (Ifni region) and produces a big pear.

Nopal cactus is employed in health, nutrition and cosmetics in the forms of tea, jam, juice and oil extracted from prickly pear seeds. It is used as a herbal remedy for diverse health problems in different countries. For instance, in the sub-Saharan traditional medicine pharmacopeia, cactus flowers and fruits are given as anti-ulcerogenic or antidiarrheal agents; flowers being also administered as an oral anti-hemorrhoid medication and cladode sap as a treatment for whooping cough. On the other hand, indigenous populations consume substantial amounts of either fresh or dry fruits as food. In these populations, cactus cladodes, fruits and flowers are featured for their interesting contents of antioxidants, pectin polysaccharides and fibers.

Recent scientific reports have highlighted the presence of natural cactus molecules, which may have high potential interest in human health and medicine [2-4]. As a general rule in herbal medicine, the extraction of bioactive compounds from permeable solid plant materials using solvents constitutes a key step in the manufacture of phytochemical-rich products. Opuntia ficus indica is known for its high content in polyphenols exhibiting antioxidant and anti-inflammatory properties [1,5]. Interestingly, alkaloids, indicaxanthin, neobetanin, and various flavonoids have been isolated from the cactus [6], along with polysaccharides which are abundant in cladode extracts and endowed with antidiabetic and antiglycation effects [7].

This review is dedicated to recent developments in the area of medically relevant compounds isolated from each of the different aerial parts (cladodes, flowers and fruits) of Opuntia ficus-indica, and to the different usages of the cactus in human foods, health promotion, disease prevention and therapy. 


\section{General Compound Content of Cactus}

Cactus fruit contains substantial amounts of ascorbic acid, vitamin E, carotenoids, fibers, amino acids and antioxidant compounds (phenols, flavonoids, betaxanthin and betacyanin) which have been put forward to account for its health benefits such as hypoglycemic and hypolipidemic action, and antioxidant properties [8-10]. Several reports have documented the abundance of vitamins and minerals in cactus [11]. In this respect, the fruit of $O$. ficus indica is a valuable source of nutrients [12] as well as antiulcerogenic [13,14], antioxidant [5,13-16], anticancer [16], neuroprotective [17], hepatoprotective [18], and antiproliferative [19] compounds. Opuntia ficus indica flowers contains different flavonoids notably kaempferol and quercetin [20]. Cactus peel and seeds can be used to prepare cactus oil, peel lipids being enriched in essential fatty acids and liposoluble antioxidants [21]. The cactus cladodes contain vitamins, antioxidants and various flavonoids, particularly quercetin 3-methyl ether, a highly efficient radical scavenger [22,23]. Cladodes of $O$. ficus-indica extracts may lower cholesterol level and convey antiulcer and anti-inflammatory mechanisms, and the water extract remarkably improves wound healing [14,24].

\section{Individual Classes of Cactus Compounds and Related Biological Activities}

Regarding its composition in polyphenols, vitamins and other specific compounds, the cactus pear appears to be an excellent candidate for nutritional diet recommendations and therapeutic indications. The spectrum of biological and medical effects reported for each class of cactus compounds is presented thereafter.

\subsection{Phenolic Compounds}

Polyphenols represent a family of organic molecules widely distributed in the plant kingdom. As suggested by their name, their chemical structures are characterized by the presence of several phenolic groups, which may be associated with more or less complex groups of chemicals, generally of high molecular weight. These compounds are usually byproducts of plant metabolism. The growing interest in polyphenols results from their antioxidant potential, which is involved in health benefits such as the prevention of inflammation [24], cardiovascular dysregulation and neurodegenerative diseases. Polyphenols have also proven anticancer activity.

All parts of the cactus plant are rich in members of the polyphenol family such as various flavonoids and phenolic acids (Table 1). In the flower, gallic acid and 6-isorhamnetin 3-O-robinobioside are the major compounds, amounting to 4900 and $4269 \mathrm{mg} / 100 \mathrm{~g}$ of dry matter, respectively [20,25-27]. Other phenolic molecules are present in small quantities not exceeding $10 \mathrm{mg} / \mathrm{g}$ (Table 2). In the fruit pulp, total phenol content is $218.8 \mathrm{mg} / 100 \mathrm{~g}$ [28], along with a high content of isorhamnetin glycosides (50.6 mg/100 g) compared to other flavonoids [14,29-32]. Fruit seeds contain high amounts of phenolic compounds ranging from 48 to $89 \mathrm{mg} / 100 \mathrm{~g}$ and including feruloyl derivatives, tannins and sinapoyl diglucoside [33] (Table 1). Interestingly, fruit peel has a very high phenol content of $45.7 \mathrm{~g} / 100 \mathrm{~g}$. Several of these phenols are bioactive molecules, notably flavonoid derivatives such as kaempherol and quercetin, the contents of which are 0.22 and $4.32 \mathrm{mg} / 100 \mathrm{~g}$, respectively [5,30,34]. Cactus flowers appear to be the most important source of polyphenols and flavonoids. 
Interestingly, some polyphenols are produced only by cladodes of some varieties of cactus such as the snowshoeing cactus. This plant presents high amounts of unusual flavonoid-like compounds such as nicotiflorin (146.5 mg/100 g) and narcissin (137.1 mg/100 g) (Table 1) along with high content values found for isoquercetin and ferulic acid: 39.67 and $34.77 \mathrm{mg} / 100 \mathrm{~g}$, respectively [4,29,35-37]. Cladode age, environment, soil type and climate could explain these variations in cactus polyphenol contents.

Table 1. Distribution and contents of phenols and flavonoids in the various parts of O. ficus-indica.

\begin{tabular}{|c|c|c|c|}
\hline Plant tissue & Main Component Identified & Content in $\mathrm{mg} / 100 \mathrm{~g}$ & References \\
\hline \multirow{8}{*}{ Flower } & Gallic acid & $1630-4900$ & \multirow{8}{*}[20,25-27]{} \\
\hline & Quercetin 3-O-Rutinoside & 709 & \\
\hline & 4 Kaempferol 3-O-Rutinoside & 400 & \\
\hline & 5 Quercetin 3-O-Glucoside & 447 & \\
\hline & 6 Isorhamnetin 3-O-Robinobioside & 4269 & \\
\hline & 7 Isorhamnetin 3-O-Galactoside & 979 & \\
\hline & 8 Isorhamnetin 3-O-Glucoside & 724 & \\
\hline & 9 Kaempferol 3-O-Arabinoside & 324 & \\
\hline \multirow{7}{*}{ Pulp } & Total phenolic acid & 218.8 & \multirow{7}{*}[13,28,29,31,32,38]{} \\
\hline & Quercetin & 9 & \\
\hline & Isorhamnetin & 4.94 & \\
\hline & Kaempferol & 0.78 & \\
\hline & Luteolin & 0.84 & \\
\hline & isorhamnetin glycosides & 50.6 & \\
\hline & Kaempferol & 2.7 & \\
\hline \multirow{6}{*}{ Seed } & Total phenolic acid & $48-89$ & \multirow{6}{*}[33]{} \\
\hline & Feruloyl-sucrose isomer 1 & $7.36-17.62$ & \\
\hline & Feruloyl-sucrose isomer 2 & $2.9-17.1$ & \\
\hline & Sinapoyl-diglucoside & $12.6-23.4$ & \\
\hline & Total Flavonoids & $1.5-2.6$ & \\
\hline & Total Tannins & $4.1-6.6$ & \\
\hline \multirow{5}{*}{ Skin fruits } & Total phenolic acid & 45,700 & \multirow{5}{*}[5,30,34]{} \\
\hline & Total Flavonoid & 6.95 & \\
\hline & Kaempferol & 0.22 & \\
\hline & Quercetin & 4.32 & \\
\hline & Isorhamnetin & $2.41-91$ & \\
\hline \multirow{11}{*}{ Cladode } & Gallic acid & $0.64-2.37$ & \multirow{11}{*}[4,29,35-37]{} \\
\hline & Coumaric & $14.08-16.18$ & \\
\hline & 3,4-dihydroxybenzoic & $0.06-5.02$ & \\
\hline & 4-hydroxybenzoic & $0.5-4.72$ & \\
\hline & Ferulicacid & $0.56-34.77$ & \\
\hline & Salicylicacid & $0.58-3.54$ & \\
\hline & Isoquercetin & $2.29-39.67$ & \\
\hline & Isorhamnetin-3-O-glucoside & $4.59-32.21$ & \\
\hline & Nicotiflorin & $2.89-146.5$ & \\
\hline & Rutin & $2.36-26.17$ & \\
\hline & Narcissin & $14.69-137.1$ & \\
\hline
\end{tabular}


Health beneficial effects of cactus polyphenols might be conditioned by their antioxidant and radical scavenging activities. For instance, gallic acid, largely found in cactus flowers, exhibits high antioxidant activity responsible for its ability to reduce DNA damage [39] and to buffer free radicals [40]. At a concentration of $4.17 \mathrm{mM}$, it may neutralize $44 \%$ of 2,2-diphenyl-1-picrylhydrazyl radical and $60 \%$ of hydrogen peroxide in given experimental conditions. Gallic acid also exerts a cytotoxic activity against tumoral cells from leukemia, lung and prostate cancer origins [41].

Opuntia ficus-indica cladodes are rich in nicotiflorin which, through antiinflammatory and neuroprotective mechanims, was shown to reduce brain infarct size, to attenuate neurological deficits induced by ischemia, and to up-regulate endothelial nitric oxide synthase in cultured rat brain vascular endothelial cells [42]. Nicotiflorin is neuroprotective against hypoxia-, glutamate- or oxidative stress-induced retinal ganglion cell death at nanomolar concentrations [43]. In a murine multi-infarct dementia model, nicotiflorin preserved spatial memory performances measured in Morris water maze tests. Besides this protective effect on memory dysfunction, nicotiflorin also protects against energy metabolism failure and oxidative stress. In ischemic brains, these beneficial effects were associated with attenuation of rises in lactic acid and malondialdehyde (MDA) and with prevention of drops in lactate dehydrogenase (LDH), $\mathrm{Na}^{+} \mathrm{K}^{+} \mathrm{ATPase}, \mathrm{Ca}^{2+} \mathrm{Mg}^{2+} \mathrm{ATPase}$ and superoxide dismutase (SOD) activities [44].

As mentioned above, the fruit peel contains large amounts of isorhamnetin. Isorhamnetin (3'-methoxy-3,4',5,7-tetrahydroxyflavone) exerts anticancer action by inhibition of epidermal growth factor (EGF)-induced neoplastic cell transformation through a direct lowering of MAP (mitogen-activated protein)/ERK (extracellular signal regulated kinase) kinase 1 and phosphoinositol 3-kinase signaling pathways [45]. Isorhamnetin exhibits cardioprotective effects by improving viability of neonatal rat ventricular myocytes under in vitro ischemia/reperfusion (I/R) via inhibition of lactate dehydrogenase (LDH) activity and prevention of apoptosis [46]. Isorhamnetin improves skin barrier function through activation of Peroxisome Proliferator-Activated Receptor (PPAR)- $\alpha$ and suppression of inflammatory cytokines production [47]. It also inhibits adipocyte differentiation of murine $3 \mathrm{~T} 3$ fibroblasts via a decrease of adiponectine expression and secretion, and downregulation of mRNAs of PPAR- $\gamma$ and $\mathrm{C} / \mathrm{EBP}-\alpha$, the major adipogenic nuclear receptors [48]. In contrast, isorhamnetin significantly increases the expression of PPAR- $\gamma$ in tumor tissues obtained from xenograft model of gastric cancer cells and, in combination with chemotherapeutic drugs, causes strong antiproliferative effects and cytotoxicity [49]. These different effects of a same PPAR ligand are explained by the fact that a ligand-activated nuclear receptor can exert different biological activities through the recruitment of their coregulator partners in a way specific to the cell type context.

\subsection{Fatty Acids}

Chromatographic analyses of total lipids extracted from cactus cladodes (Table 2) [50] show that palmitic acid (C16:0), oleic acid (C18:1), linoleic acid (C18:2), linolenic acid (C18:3) contribute $13.87,11.16,34.87$ and $32.83 \%$ of the total fatty acid content, respectively (Table 1). These four fatty acids thus represent over $90 \%$ of total fatty acids with linoleic and linolenic acids, the major polyunsaturated fatty acids, amounting to $67.7 \%$. The linoleic acid content in cactus cladode (34.87\%) 
is thus close to the percentage (29\% to $40.41 \%)$ found in argan oil [51]. It is however lower than in extracts from barely $(51.26 \%)$ and soybean $(53.0 \%)$, respectively (Table 2) [50].

Table 2. Comparison of the fatty acid composition of $O$. ficus-indica and other edible oils Compositions are expressed in $\mathrm{g} / 100 \mathrm{~g}$ fatty acids.

\begin{tabular}{|c|c|c|c|c|c|c|c|c|c|c|c|c|c|}
\hline Fatty Acid & C12:0 & C14:0 & C16:0 & C16:1 & C18:0 & C18:1 & C18:2 & C18:3 & C20:0 & C22:0 & C22:1 & C24:0 & Reference \\
\hline Cladode & 1.33 & 1.96 & 13.87 & 0.24 & 3.33 & 11.16 & 34.87 & 33.23 & - & - & - & - & {$[50]$} \\
\hline Cactus seed oil & - & - & 20.1 & 1.80 & 2.72 & 18.3 & 53.5 & 2.58 & - & - & - & - & [52] \\
\hline Cactus seed oil & - & - & 9.32 & 1.42 & 3.11 & 16.77 & 70.29 & nd & - & - & - & - & [53] \\
\hline Fruits pulp oil & - & 1.13 & 34.4 & 1.62 & 2.37 & 10.8 & 37 & 12.68 & - & - & - & - & [52] \\
\hline Prickly pear peel & 0.71 & 1.95 & 23.1 & 2.48 & 2.67 & 24.1 & 32.3 & 9.27 & nd & 0.5 & - & 0.41 & [21] \\
\hline Argan oil & - & 0.10 & 11.7 & 0.14 & 4.9 & 36.6 & 31.3 & 0.09 & 0.33 & 0.12 & - & 0.06 & [54] \\
\hline Olive oil & - & 11.5 & 0.9 & 1.4 & 61.9 & 3.8 & 1.1 & 0.23 & - & - & - & - & {$[55]$} \\
\hline Grape seed oil & - & 0.06 & 8.3 & 0.1 & 3 & 12 & 67.6 & 0.3 & 0.2 & 0.1 & 0.02 & 0.01 & {$[56]$} \\
\hline Soybean oil & - & - & 6 & 0.4 & 2.2 & 26.1 & 50.1 & 14.5 & - & - & - & - & [57] \\
\hline Corn oil & - & - & 13.4 & Traces & 1.5 & 27.4 & 56 & 0.9 & 0.2 & - & - & - & {$[58]$} \\
\hline Sunflower oil & - & 0.08 & 7.4 & 0.09 & 4.56 & 25.17 & 60.15 & 0.3 & - & - & - & 0.34 & [59] \\
\hline
\end{tabular}

Several studies have indicated that cactus particularly; fruits, pulp, seed and pickely pear peel were rich in linolenic, oleic and palmitic acids $[21,52,53,60]$. High level of omega-6 linoleic acid was reported in cactus seed oil (53.5\% to $70.29 \%$ ) (Table 1$)$, and this level is higher than in sunflower oil [59], grape seed oil or sesame oil. As a precursor of arachidonic acid, linoleic acid has long been accepted as having a hypocholesterolemic effect and inhibitory properties against colon cancer metastatic cells [61]. Omega-3 linolenic acid is known to be beneficial for health, cardiovascular diseases, inflammatory conditions, autoimmune disorder and diabetes.

\subsection{Vitamins}

The Opuntia ficus indica develops a fruit known as cactus pear, a fleshy bay (pulp) containing seeds and enveloped by a prickly peel (skin). The fruit, particularly its skin, is enriched in vitamin $\mathrm{E}$ at amounts up to $17.6 \mathrm{~g} / \mathrm{kg}$ of $\alpha$-tocopherol (Table 3). In contrast, the oil extracted from the fruit's seeds has a low content in vitamin E: $0.403 \mathrm{~g} / \mathrm{kg}$, mostly $\gamma$-tocopherol $(0.330 \mathrm{~g} / \mathrm{kg})[21,52,60]$. Such an amount is very low compared to argan oil content $(7.6$ to $8.6 \mathrm{~g} / \mathrm{kg})[62,63]$. The essential oil extracted from the fruit's pulp is rich in $\sigma$-tocopherol with $4.220 \mathrm{~g} / \mathrm{kg}$ (Table 3). Cactus pear contains 180 to 300 $\mathrm{mg} / \mathrm{kg}$ of vitamin C. This content is higher than that found in other common fruits like apple, banana, or grape [64]. Vitamin $\mathrm{K} 1$ is present in all parts of the fruit, ranging from 0.5 to $1 \mathrm{~g} / \mathrm{kg}[52,60]$. Vitamin B is present only in the cladodem in which it is found in trace amounts [65]. To our knowledge, the precise vitamin contents in flowers of Opuntia ficus indica still remains to be elucidated. 
Table 3. Distribution and contents of vitamins in the different parts of fruit and cladode from prickly pear of $O$. ficus-indica. Vitamin contents are expressed as $\mathrm{mg} / 100 \mathrm{~g}$ tissue.

\begin{tabular}{cccccc}
\hline & Pulp & Seeds & Skin & Cladode & Source \\
\hline Vitamin K1 & 53.2 & 52.5 & 109 & ---- & \\
Vitamin C, & $34-40$ & ---- & ---- & $7-22$ & \\
Vitamin B1 & ---- & ---- & ---- & 0.14 & \\
Vitamin B2 & ---- & ---- & ---- & 0.60 & \\
Vitamin B3 & ---- & ---- & ---- & 0.46 & {$[5,21,28,31,32,60,66]$} \\
$\alpha$-Tocopherol, & 84.9 & 56 & 1760 & ---- & \\
$\beta$-Tocopherol, & 12.6 & 12 & 222 & ---- & \\
$\gamma$-Tocopherol, & 7.9 & 33 & 174 & ---- & \\
$\sigma$-Tocopherol & 422 & 5 & 26 & ---- & \\
Total vitamin E & 527.4 & 106 & 2182 & ---- & \\
\hline
\end{tabular}

\subsection{Sterols}

Ramadan and Morsel [52,60], have documented $\beta$-sitosterol as the major sterol extracted from different parts of the fruit oils: pulp, skin and seeds, with a content ranging from 6.75 to $21.1 \mathrm{~g} / \mathrm{kg}[52,60]$. Campesterol is present in the pulp, seed and skin, in an amount of 1.66 to $8.76 \mathrm{~g} / \mathrm{kg}$ (Table 4). Similar contents of campesterol are found in some other food oils such as argan oil (4 g/ kg) [67], whereas higher contents have been measured in soybean oil (between 19 and $23 \mathrm{~g} / \mathrm{kg}$ ) [67]. Other sterols are found in small quantities notably stigmasterol, lanosterol, avenasterol $\Delta^{5}, \Delta^{7}$-avenasterol, $\Delta^{7}$-avenasterol and ergosterol, So far, sterol composition of the essential oil of cladode and flowers remains to be determined. In comparison with cactus, in argan oil, for instance, sterols such as spinasterol and schottenol have been identified [67].

Table 4. Distribution and contents of sterols in the various parts of the O. ficus-indica fruit including pulp, seeds and skin. Sterol contents are expressed in $\mathrm{g} / \mathrm{kg}$.

\begin{tabular}{lcccc}
\hline \multicolumn{1}{c}{ Main Component Identified } & Pulp & Seed & Skin & References \\
\hline Campesterol & 8.74 & 1.66 & 8.76 & \\
Stigmasterol & 0.73 & 0.30 & 2.12 & \\
Lanosterol & 0.76 & 0.28 & 1.66 & \\
$\beta$-Sitosterol & 11.2 & 6.75 & 21.1 & {$[21,60]$} \\
$\Delta^{5}$-Avenasterol, $\Delta^{7}$-Avenasterol & 1.43 & 0.29 & 2.71 & \\
$\Delta^{7}$-Avenasterol & ---- & 0.05 & ---- & \\
Ergosterol & ---- & ---- & 0.68 & \\
\hline
\end{tabular}

\subsection{Mineral Compounds}

Cactus fruit's seeds are rich in minerals, with a predominance of potassium and phosphorus at 163 and $152 \mathrm{mg} / 100 \mathrm{~g}$ (Table 5), respectively. Remarkable also is the presence of large quantities (given in $\mathrm{mg} / 100 \mathrm{~g}$ ) of magnesium (74.8), sodium (67.6) and calcium (16.2) (Table 5) [68-70]. In cladode, the major minerals are potassium and calcium, with amounts ranging from 235 to $5520 \mathrm{mg} / 100 \mathrm{~g}$ 
(Table 5) [65,71,72]. In pulp, potassium is present at $161 \mathrm{mg} / 100 \mathrm{~g}$, exceeding the concentration of other minerals like calcium and magnesium (Table 5) [70,73].

Table 5. Distribution and contents of minerals in the various parts of $O$. ficus-indica. Mineral contents are expressed as $\mathrm{mg} / 100 \mathrm{~g}$.

\begin{tabular}{lcccc}
\hline \multicolumn{1}{c}{ Main component identified } & Pulp & Seed & Cladode & References \\
\hline Calcium & 27.6 & 16.2 & $5.64-17.95$ & \\
Calcium oxalate & ---- & --- & 11.5 to 4.3 & \\
Magnesium & 27.7 & 74.8 & 8.80 & \\
Sodium & 0.8 & 67.6 & $0.3-0.4$ & \\
Potassium & 161 & 163 & $2.35-55.20$ & \\
Iron & 1.5 & 9.45 & 0.09 & {$[65,66,70-72,74]$} \\
Phosphorus & ---- & 152 & $0.15-2.59$ & \\
Zinc & ---- & 1.45 & 0.08 & \\
Copper & ---- & 0.32 & ---- & \\
Manganese & ---- & Trace & $0.19-0.29$ & \\
\hline
\end{tabular}

\subsection{Amino Acids}

In cactus cladodes, the major amino acid detected is glutamine, followed by leucine, lysine, valine, arginine, phenylalanine and isoleucine. By contrast, in cactus seed the major amino acid is glutamic acid at a percentage varying from $15.73 \%$ to $20.27 \%$, followed by arginine, ( $4.81 \%$ to $14.62 \%)$ (Table 6) $[75,76]$. Interestingly, in the cactus fruit, the two predominant amino acids are proline and taurine, which represent $46 \%$ and $15.78 \%$ of the total amino acid content, respectively. Total proteins in fruit seeds (13.62\%) are higher than in cladodes (4\%-10\%) (Table 6) [75,76]. Thus, fruit seeds and pulp can be considered as very good sources of amino acids and proteins [75-77].

Table 6. Distribution and contents of amino acids content in seeds, cladode and fruit juice from O. ficus-indica. Amino acid contents are expressed as $\mathrm{g} / 100 \mathrm{~g}$.

\begin{tabular}{ccccc}
\hline Amino Acid & Cladode & Fruit & Seeds & References \\
\hline Alanine & 1.25 & 3.17 & 4.75 & \\
Arginine & 5.01 & 1.11 & 6.63 & \\
Asparagine & 3.13 & 1.51 & Trace & \\
Asparaginic acid & 4.38 & Trace & 10.42 & \\
Glutamic acid & 5.43 & 2.40 & 21.68 & \\
Glutamine & 36.12 & 12.59 & Trace & \\
Cystine & 1.04 & 0.41 & 0.37 & {$[65,73]$} \\
Histidine & 4.18 & 1.64 & 3.11 & \\
Isoleucine & 3.97 & 1.13 & 6.20 & \\
Leucine & 2.71 & 0.75 & 9.94 & \\
Lysine & 5.22 & 0.63 & 6.79 & \\
Methionine & 2.92 & 2.01 & 0.70 & \\
Phenylalanine & 3.55 & 0.85 & 5.25 & \\
Serine & 6.68 & 6.34 & 8.46 & \\
\hline
\end{tabular}


Table 6. Cont.

\begin{tabular}{ccccc}
\hline Amino acid & Cladode & Fruit & Seeds & References \\
\hline Threonine & 4.18 & 0.48 & 1.53 & \\
Tyrosine & 1.46 & 0.45 & 3.09 & \\
Tryptophane & 1.04 & 0.46 & Trace & \\
Valine & 7.72 & 1.43 & 6.02 & \\
a-Aminobutyric acid & Trace & 0.04 & Trace & \\
Carnosine & Trace & 0.21 & Trace & {$[65,73]$} \\
Citrulline & Trace & 0.59 & Trace & \\
Ornithine & Trace & Trace & Trace & \\
Proline & Trace & 46.00 & Trace & \\
Taurine & Trace & 15.79 & Trace & \\
Glycine & Trace & Trace & 5.06 & \\
\hline
\end{tabular}

\section{Cactus and Compounds in Nutritional and Medical Practice}

\subsection{Cactus in Nutrition and Prevention of Disease}

The nutritional value of cactus pear fruit mainly rests on its content in ascorbic acid, vitamin E, carotenoids, fibers, amino acids, and on large amounts of glucose and fructose. Prickly pears are also rich in phenols, flavonoids, betaxanthins and betacyanins (Figure 1 and Table 7), which favor a healthy status through hypoglycaemic and hypolipidemic actions, and antioxidant properties [4,8-10]. Remarkably, among existing natural pigments betalains are present at high amount in cactus. Regarding consumers' increasing aversion for synthetic colorants, natural colorants, such as the red betacynins and the yellow betaxanthins, represent a good natural alternative to meet the growing demand of the food industry. The antioxidant properties of these betalain pigments represent an additional argument in favor of the development of their use in nutrition and health [78-80].

Figure 1. General structure of betalamic acid (a), betacyanins (b) and betaxanthins (c) [81].

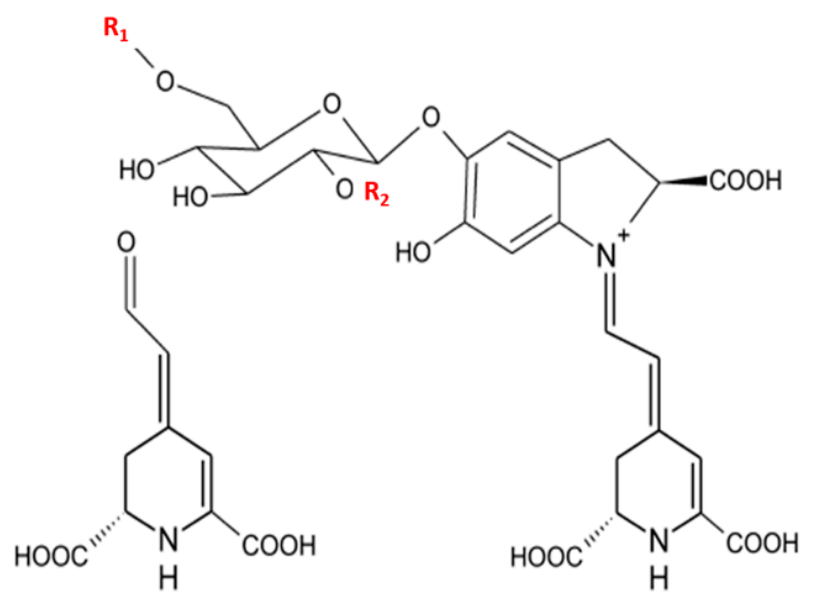

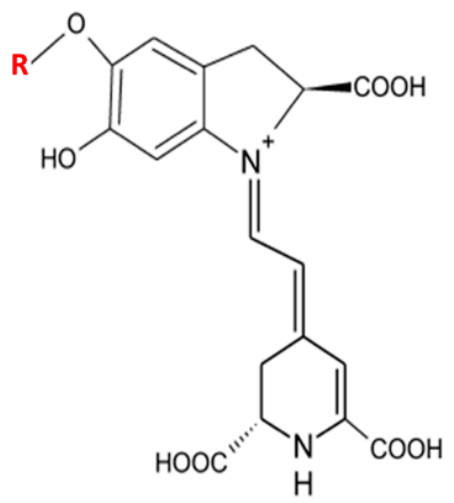

(b)<smiles>[R5][NH+]=CC=C1C=C(C(=O)O)N[C@H](C(=O)O)C1</smiles>

(c) 
Table 7. Names of betaxanthins and betacyanins present in Opuntia spp.

\begin{tabular}{|c|c|c|c|c|}
\hline Compounds & Name & Radical & Opuntia Specie & References \\
\hline \multirow{19}{*}{ Betaxanthins } & Portulacaxanthin I & R3 = hydroxyproline & O. ficus-indica & [78] \\
\hline & Portulacaxanthin III & R3 = glycine & O. ficus-indica & {$[78,81]$} \\
\hline & Muscaaurin & R3 $=$ histidine & O. robusta, O. ficus-indica, O. megacantha & {$[78,82]$} \\
\hline & & & O. robusta Wendl, O. robusta, O. streptacantha & \\
\hline & Indicaxanthin & $\mathrm{R} 3=$ proline & Lemaire, O. ficus-indica, O. megacantha, & {$[12,78]$} \\
\hline & & & O. albi-carpa & \\
\hline & $(S)$-serine-betaxanthin & $\mathrm{R} 3=$ serine & O. ficus-indica & {$[78,81]$} \\
\hline & $(S)$-valine-betaxanthin & $\mathrm{R} 3=$ valine & O. ficus-indica & [81] \\
\hline & $(S)$-isoleucine-betaxanthin & $\mathrm{R} 3=$ isoleucine & O. ficus-indica & [81] \\
\hline & $\gamma$-Aminobutyric acid-Bx & $\mathrm{R}=$ butyric acid & O. spp & [82] \\
\hline & Methionine-betaxanthin & $\mathrm{R} 3=$ methionine & O. spp & [82] \\
\hline & (S)- Phenylalaine-betaxanthin & $\mathrm{R} 3=$ phenylalaine & O. ficus-indica & [81] \\
\hline & Vulgaxanthin I & $\mathrm{R} 3=$ glutamine & O. robusta Wendl, O. ficus-indica & [81] \\
\hline & & & O. streptacantha; O. beta vulgaris L.spp. V. Pablo; & \\
\hline & Vulgaxantin Ii & $\mathrm{R}=$ glutamic acid & O. bergeriana; O. ficus indica; O. alba-carba; & [82] \\
\hline & & & O. robusta and $O . S p p$ & \\
\hline & Vulgaxantin III & $\mathrm{R}=$ asparagine & $\begin{array}{l}\text { O. streptacantha; O. beta vulgaris L.spp. V. Pablo; } \\
\text { O. alba-carba; O. robusta and O. Spp }\end{array}$ & [82] \\
\hline & Vulgaxanthin IV & $\mathrm{R} 3=$ leucine & $\begin{array}{l}\text { O. streptacantha; O. beta vulgaris; O. alba-carba; } \\
\text { O. robusta Wendl, O. ficus-indica }\end{array}$ & {$[78,81]$} \\
\hline & Miraxanthin II & $\mathrm{R} 3=$ aspartic acid & O. bergeriana; $O$. ficus indica & [12] \\
\hline \multirow{9}{*}{ Betacyanins } & & & O. robusta Wendl, O. robusta, O. streptacantha & \\
\hline & Betanin & $\mathrm{R} 1=\mathrm{R} 2=\mathrm{H}$ & Lemaire, O. ficus-indica, O. megacantha, & {$[8,12,78,82]$} \\
\hline & & & O. albi-carpa, O. xoconostle & \\
\hline & iso-Betanin & $\mathrm{R} 1=\mathrm{R} 2=\mathrm{H}$ & $\begin{array}{l}\text { O. robusta Wendl, O. robusta, O. streptacantha } \\
\text { Lemaire, O. ficus-indica, O. xoconostle }\end{array}$ & {$[8,78,82]$} \\
\hline & & & O. robusta Wendl, O. robusta, O. streptacantha & \\
\hline & Betanidin & $\mathrm{R}=\mathrm{H}$ & Lemaire, O. ficus-indica, O. megacantha, & {$[8,12,78,82]$} \\
\hline & & & O. xoconostle & \\
\hline & Gomphrenin i & $\mathrm{R} 1=\mathrm{R} 2=\mathrm{H}$ & O. robusta Wendl, O. robusta, O. ficus-indica & {$[78,82]$} \\
\hline & Phyllocactin & $\mathrm{R} 1=$ malonyl $\mathrm{R} 2=\mathrm{H}$ & O. xoconostle & {$[8,12,81,82]$} \\
\hline
\end{tabular}

\subsection{Cactus in Health and Disease}

Diverse benefits of cactus extracts and cactus compounds have been suggested by the traditional medicine uses (see below). Meanwhile, these benefits have progressively received a scientific basis thanks to numerous experimental models dedicated to the evaluation of cactus compounds to treat different diseases. Therapeutic potential has been suggested for metabolic syndrome (including diabetes type 2 and obesity), non-alcoholic fatty liver disease (NAFLD), rheumatism, cerebral ischemia, cancers, and virological and bacterial infections [83-86]. Interestingly, cactus preparations might exert preventive and therapeutic effects against alcoholism and alcohol addiction [87].

On the basis of our current knowledge of redox biology of normal and diseased cells, including cancer ones, the concept of "antioxidant" activity of phytochemicals has to be carefully evaluated. It 
should be recalled that action mechanisms of phytochemicals might be different according to the context. Indeed, although ROS can promote cell damage, inflammation and cancer, the so-called antioxidants, including the dietary "antioxidants" may fail to protect, and may even be dangerous for healthy cells under certain conditions. It should also be kept in mind that ROS are necessary to cells, where they play important roles, and serve the essential function to maintain the peroxide or nucleophilic tone governing all cell functions. Redox-active phytochemicals (or products from their transformation after absorption) are possibly used by cells to cause adaptive responses allowing induction of molecular defenses or block of dangerous processes, which may be different from cell to cell and from healthy to malignant cells.

\subsection{Cactus Use in Traditional Medicine}

In traditional medicine, Opuntia ficus indica has been used for the treatment of burns, wounds, edema, hyperlipidemia, obesity and catarrhal gastritis. Alcoholic extracts are indicated for anti-inflammatory, hypoglycemic, and antiviral purposes [84].

\section{Medical Relevance of Cactus Compounds: The State of the Art}

\subsection{Experimental Models and Randomized Trials}

Experiments on animal and cell models have highlighted therapeutic potentialities of cactus extracts or compounds through their impacts on key parameters involved in diseases previously targeted by traditional herbal medicines. These scientific studies and bodies of experimental proofs have strengthened the attraction of the pharmacological industry for exploring cactus as a tool to identify new natural bioactive leads and to develop new nutritional supplementations or formulations.

\subsection{Pharmacological Potentials of Antioxidant and Antiinflammatory Effects of Cactus}

In vitro and in vivo studies are convergent to conclude that Opuntia ficus indica extracts exhibit antioxidant and anti-inflammatory properties. The models and conditions, in which these cactus compound properties are highlighted, obviously support that they may be subject to further pharmacological exploration and development.

\subsubsection{In Vitro Studies (on Intact Cells)}

Oxidative stress and inflammation are involved in numerous diseases. Many studies support the fact that many dietary redox active/antioxidant and anti-inflammatory phytochemicals are promising compounds to prevent oxidative and inflammatory mechanisms taking place in many pathological states. In human intestinal epithelial cancer cells (Caco-2) stimulated by IL-1 $\beta$, co-treatment with indicaxanthin (a pigment from the edible fruit of Opuntia ficus-indica) prevents activations of NOX-1 and NF-kB and attenuates the rise in inducible NO synthase [88]. These data suggest that cactus dietary pigments may directly influence intestinal inflammatory mechanisms [88]. In human chondrocyte cultures stimulated with IL-1 $\beta$, lyophilized extracts of Opuntia ficus-indica cladodes reduce the production of key molecules usually released upon chronic inflammation such as nitric 
oxide (NO), glycosaminoglycans, prostaglandin-E2 (PGE-2) and reactive oxygen species [89]. For this reason, lyophilized extracts of Opuntia ficus indica cladodes might have a pharmacological interest in preventing cartilage alterations and in treating joint disease. On human umbilical vein endothelial cells (HUVECs), non-cytotoxic micromolar concentrations of betalain (a pigment of Opuntia ficus-indica purified from fresh pulp of cactus pear) decrease the expression of cell adhesion molecules such as ICAM-1 [90]. Because it has also radical scavenging/antioxidant properties [90], betalain exhibits an interesting pharmacological profile for degenerative disorders affecting endothelial function such as atherosclerosis, atherothrombosis, low limb ischemia, and stroke. On the murine microglial cell line (BV-2), a butanol fraction (obtained from 50\% ethanol extracts of Opuntia ficus indica and hydrolysis products) inhibits the production of NO in LPS-activated BV-2 cells via suppression of iNOS protein and mRNA expressions, inhibits the degradation of IкB- $\alpha$, and displays peroxynitrite scavenging activity [91]. Moreover, in cultured mouse cortical cells, the butanol fraction of Opuntia ficus indica significantly reduces $N$-methyl-D-aspartate-, kainate-, and oxygen-glucose deprivation-induced delayed neurotoxicity [92]. These results support that Opuntia ficus indica might alleviate neuronal damages resulting or not from microglial activation.

\subsubsection{In Vivo Studies (on the Whole Animals)}

In a rat model of acute inflammation (pleurisy), the oral administration of indicaxanthin (mentioned above) reduces exudate size and leukocytes recruitment in the pleural cavity, as well as the protein and/or mRNA expressions of PGE-2, NO, IL-1 $\beta$, iNOS, and cyclooxygenase-2 (COX2) in the recruited leukocytes [93]. In gerbils, protective effects of methanol extracts of Opuntia ficus indica given per os were also observed against neuronal damages caused by global ischemia in the hippocampal region [92].

\subsection{Pharmacological Potentialities of Cactus Effects on Non-Alcoholic Fatty Liver Disease}

Non-alcoholic fatty liver disease is a complex pathology involving oxidative stress, inflammation, and cell death. Noteworthy, when obese Zucker $(f a / f a$ ) rats are fed with a diet containing $4 \%$ Opuntia ficus indica for 7 weeks, the rats have around 50\% lower hepatic triglycerides than the control group along with a reduction of hepatomegaly and biomarkers of hepatocyte injury (alanine and aspartate aminotransferases). A higher concentration of adiponectin and a greater abundance of genes involved in lipid peroxidation, lipids export and production of carnitine palmitoyltransferase- 1 and microsomal triglyceride transfer proteins are observed in livers from cactus-treated animals. Furthermore, rats fed with cactus have a lower postprandial serum insulin concentration and a greater phosphorylated protein kinase B (pAkt):Akt ratio in the postprandial state [94]. Altogether, data obtained in obese Zucker $(f a / f a)$ rats fed with Opuntia ficus indica support that cactus consumption attenuates hepatic steatosis, a pathology currently under the radar screen of the pharmacological industry.

\subsection{Pharmacological Potentials of Antimicrobial Activities of Cactus}

Campylobacter is one of the most common agent causative of food-borne bacterial gastroenteritis in the humans. Epidemiological studies reveal that consumption of poultry products represents an 
important risk factor of this disease. Noteworthy, the extracts of Opuntia ficus indica have marked bactericidal effects on the growth of Campylobacter jejuni and Campylobacter coli. Moreover, adherence of Campylobacter to Vero cells is strongly reduced [95].

Antimicrobial activities of methanolic, ethanolic, or aqueous extracts of Opuntia ficus indica have also been studied on Vibrio cholerae, indicating that the methanolic extract was the most efficient [96]. This extract causes membrane disruption, leading to increased membrane permeability and consequent marked decreases in $\mathrm{pH}$ and ATP.

Altogether, these data obviously support a pharmacological interest of Opuntia ficus indica preventing food contamination by Campylobacter and Vibrio cholerae and in treating gut tract disorders associated with these microorganisms.

\subsection{Pharmacological Potentials in Targeting Alcoholism with Cactus Extracts}

Several studies have evaluated the benefits of Opuntia ficus indica against symptoms of alcohol hangover in humans. The cause of severity of the alcohol hangover can be, at least in part, inflammation and disruption of lipid metabolism homeostasis. In the rat, the effect of mucilage obtained from cladodes on the healing of ethanol-induced gastritis seems correlated with a (re)stabilization of plasma membranes in damaged gastric mucosa. Molecular interactions between mucilage monosaccharides and membrane phospholipids (mainly phosphatidylcholine and phosphatidylethanolamine) may represent the molecular basis for changes in the functions of membrane-attached proteins observed during the healing process consecutive to chronic gastric mucosal damages [97]. Moreover, in humans, an extract of the Opuntia ficus indica plant has been reported to reduce the symptoms of alcohol hangover like nausea, dry mouth, and anorexia [98].

\subsection{Side Effects Caused by Cactus Compounds}

Little information is currently available on cactus side effects. To date, a low colonic obstruction has been attributed to the consumption of Opuntia ficus indica seeds [99].

\section{Conclusions}

During the last decade, growing interest in cactus has resulted in a large number of scientific papers describing the composition and/or the bioactivity of a whole extract or a specific purified cactus compounds. Beside the compound contents of Optunia ficus-indica, this review has also devoted a special effort to account for the biological activities of the different parts of the cactus plant (summarized in Table 8). Interestingly, data from several human trials or rodent experiments show that cladodes and fruits extracts are the cactus preparations the most widely tested for their biological activities. Accordingly, as potential metabolic regulators, cactus extracts reveal beneficial effects on the metabolisms of both lipid and glucose, which bode well for the treatment of human metabolic disorders including diabetes and obesity. On the other hand, antioxidant and anti-inflammatory properties of cactus pear and cladodes need to be explored in depth to better understand biological activities and preventive potentials exhibited against several age-linked diseases by polyphenols and flavonoids abundant in cactus pear. At the nutritional level, cactus may be used as an alternative source 
of natural colors and nutriments, via supply in betalains, aminoacids, sugars, proteins and vitamins. The latter compounds offer a high nutritional value to the food industry for which the development of a real cactus-sourcing branch is awaited.

Table 8. Major bioactive effects of cactus preparations in different experimental models.

\begin{tabular}{|c|c|c|c|}
\hline Biological Activity & Source of Cactus Products & In Vivo and in Vitro Models & References \\
\hline \multirow{3}{*}{$\begin{array}{l}\text { Hypolipidemic and } \\
\text { Hypocholesterolemic }\end{array}$} & Cladodes powder & Rats & {$[14]$} \\
\hline & Cladodes (Glycoproteine) & Mice & {$[100]$} \\
\hline & Seeds powder and seeds oil & Rats & {$[53]$} \\
\hline \multirow{4}{*}{ Anti-diabetic } & Capsule: cladode and fruit skin extract & Human & {$[101]$} \\
\hline & Cactus powder in capsule & Human (Man and women) & {$[102]$} \\
\hline & $\begin{array}{l}\text { Aqueous extract of the cladode and fruit } \\
\text { and mixture }\end{array}$ & Rats & {$[103]$} \\
\hline & Cladode and fruit skin extract capsule & Man & {$[104]$} \\
\hline \multirow{2}{*}{ Hypoglycemic } & Polysaccharide extract from the cladode & Rats & {$[105]$} \\
\hline & Extract powder racket after drying & Rats & {$[106]$} \\
\hline \multirow{5}{*}{ Anti-Inflammatory } & Indicaxanthin, from fruit & $\begin{array}{l}\text { Human intestinal epithelial cell line (Caco- } 2 \\
\text { cells) stimulated by cytokine IL-1b }\end{array}$ & {$[88]$} \\
\hline & Lyophilized extracts of cladodes & $\begin{array}{l}\text { Human chondrocyte cultures stimulated with } \\
\text { IL-1 } \beta\end{array}$ & [89] \\
\hline & Indicaxanthin from Cactus Pear Fruit & $\begin{array}{l}\text { Rat Pleurisy obtained by injection of } 0.2 \mathrm{ml} \text { of } \\
\lambda \text {-carrageenin into the pleural cavity }\end{array}$ & {$[93]$} \\
\hline & $\begin{array}{l}\text { Methanol extract of cactus stems (active } \\
\text { substance: } \beta \text {-sitosterol) }\end{array}$ & Mice (male) & {$[107]$} \\
\hline & $\begin{array}{l}\text { Methanolic extracts of prickly pear fruits } \\
\text { (Betalain Indicaxanthin) }\end{array}$ & $\begin{array}{l}\text { In vitro study of the interaction between } \\
\text { purified Betalains and HOCL and human } \\
\text { myeloperoxidase }\end{array}$ & {$[93,108]$} \\
\hline $\begin{array}{l}\text { Anti-Inflammatory and } \\
\text { Antioxidant }\end{array}$ & Butanol and methanol fruit extract & $\begin{array}{l}\text { In vivo studies in gerbils and In vitro studies } \\
\text { in cultured mouse cortical cells }\end{array}$ & {$[92]$} \\
\hline \multirow{9}{*}{ Antioxidant } & $\begin{array}{l}\text { Betalain a pigment purified from fresh } \\
\text { pulp of cactus pear }\end{array}$ & $\begin{array}{l}\text { Endothelial cells human umbilical vein } \\
\text { (HUVEC) }\end{array}$ & {$[90]$} \\
\hline & Betanin prickly pear fruit Extracts & $\begin{array}{l}\text { Chemical and biological (human RBC, LDL) } \\
\text { systems }\end{array}$ & {$[1]$} \\
\hline & Ethanol extract of the stem & $\begin{array}{l}\text { Chemical and biological systems (mouse } \\
\text { splenocytes) }\end{array}$ & {$[22]$} \\
\hline & Flavonoid fraction of juice of whole fruits & Rats & {$[18]$} \\
\hline & Glycoprotein $(90 \mathrm{kDa})$ isolated from & & \\
\hline & Opuntia ficus-indica var. saboten & Mice induced by Triton WR-1339 & {$[100]$} \\
\hline & MAKINO & & \\
\hline & Cactus pear fruit & $\begin{array}{l}\text { Healthy humans ( } 10 \text { women and } 8 \text { men) } \\
\text { supplemented with cactus pear or Vit C }\end{array}$ & [109] \\
\hline & $\begin{array}{l}\text { Quercetine ether 3-O-méthyl isolated from } \\
\text { Opuntia ficus-indica var. saboten }\end{array}$ & Primary cultured rat cortical cells & {$[17]$} \\
\hline
\end{tabular}


Table 8. Cont.

\begin{tabular}{|c|c|c|c|}
\hline Biological Activity & Source of Cactus Products & In Vivo and in Vitro Models & References \\
\hline \multirow{4}{*}{ Antimicrobial } & Methanol extract of cladode & $\begin{array}{l}\text { Bacteria: Campylobacter jejuni and } \\
\text { Campylobacter coli }\end{array}$ & {$[95]$} \\
\hline & $\begin{array}{l}\text { Methanolic, ethanolic, and aqueous } \\
\text { extracts of cladode }\end{array}$ & Bacteria: Vibrio cholerae & [96] \\
\hline & Hexane extracts from flowers & $\begin{array}{l}\text { Bacteria: Staphylococcus aureus, Escherichia } \\
\text { coli, Pseudomonas aeruginosa and Bacillus } \\
\text { subtilis }\end{array}$ & [110] \\
\hline & Aqueous and alcoholic extracts of cladode & Bacteria: Proteus mirabilis & [111] \\
\hline
\end{tabular}

\section{Acknowledgments}

This work was supported by the Action Intégrée of the Comite Mixte Inter-universitaire Franco-Marocain (CMIFM, AIMA/14/310, Campus France) from the PHC Volubilis/Toubkal program, Ministère des Affaires Etrangères, the Conseil Régional de Bourgogne, the Ministère de l'enseignement et de la Recherche and The Projet Sectoriel CNRST.

\section{Author Contributions}

$\mathrm{KE}, \mathrm{YE}$ and $\mathrm{AB}$ : collected data from the literature and prepared tables and figure. PA: involved in writing the manuscript and formatting the references. JV was deeply involved in the manuscript correction and revision. JV and MSE: involved in general supervision of the review. NL and GL: Involved in writing several paragraphs and revision. BN and MC-M: Designed the review, revised the manuscript and supervised the collected data by KE, YE and AB. All authors have read and approved the manuscript.

\section{Conflicts of Interest}

The authors declare no conflict of interest.

\section{References}

1. Butera, D.; Tesoriere, L.; di Gaudio, F.; Bongiorno, A.; Allegra, M.; Pintaudi, A.M.; Kohen, R.; Livrea, M.A. Antioxidant activities of sicilian prickly pear ( Opuntia ficus indica) fruit extracts and reducing properties of its betalains: Betanin and indicaxanthin. J. Agric. Food Chem. 2002, 50, 6895-6901.

2. Alimi, H.; Hfaiedh, N.; Bouoni, Z.; Hfaiedh, M.; Sakly, M.; Zourgui, L.; Rhouma, K.B. Antioxidant and antiulcerogenic activities of Opuntia ficus indica $\mathrm{f}$. inermis root extract in rats. Phytomedicine 2010, 17, 1120-1126.

3. Morales, P.; Ramírez-Moreno, E.; de Cortes Sanchez-Mata, M.; Carvalho, A.M.; Ferreira, I.C.F.R. Nutritional and antioxidant properties of pulp and seeds of two xoconostle cultivars (Opuntia joconostle F.A.C. Weber ex Diguet and Opuntia matudae Scheinvar) of high consumption in Mexico. Food Res. Int. 2012, 46, 279-285. 
4. Valente, L.M.M.; da Paixão, D.; do Nascimento, A.C.; dos Santos, P.F.P.; Scheinvar, L.A.; Moura, M.R.L.; Tinoco, L.W.; Gomes, L.N.F.; da Silva, J.F.M. Antiradical activity, nutritional potential and flavonoids of the cladodes of Opuntia monacantha (Cactaceae). Food Chem. 2010, 123, 1127-1131.

5. Kuti, J.O. Antioxidant compounds from four Opuntia cactus pear fruit varieties. Food Chem. 2004, 85, 527-533.

6. Valente, L.; Scheinvar, L.; da Silva, G.; Antunes, A.; dos Santos, F.; Oliveira, T.; Tappin, M.; Aquino Neto, F.; Pereira, A.; Carvalhaes, S.; et al. Evaluation of the antitumor and trypanocidal activities and alkaloid profile in species of Brazilian Cactaceae. Pharmacogn. Mag. 2007, 3, 167-172.

7. Yang, N.; Zhao, M.; Zhu, B.; Yang, B.; Chen, C.; Cui, C.; Jiang, Y. Anti-diabetic effects of polysaccharides from Opuntia monacantha cladode in normal and streptozotocin-induced diabetic rats. Innov. Food Sci. Emerg. Technol. 2008, 9, 570-574.

8. Osorio-Esquivel, O.; Alicia-Ortiz-Moreno; Álvarez, V.B.; Dorantes-Álvarez, L.; Giusti, M.M. Phenolics, betacyanins and antioxidant activity in Opuntia joconostle fruits. Food Res. Int. 2011, 44, 2160-2168.

9. Paiz, R.C.; Juárez-Flores, B.I.; Aguirre, R.J.R.; Cárdenas, O.C.; Reyes, A.J.A.; García, C.E.; Álvarez, F.G. Glucose-lowering effect of xoconostle (Opuntia joconostle A. Web. Cactaceae) in diabetic rats. J. Med. Plants Res. 2010, 4, 2326-2333.

10. Schaffer, S.; Schmitt-Schillig, S.; Müller, W.E.; Eckert, G.P. Antioxidant properties of Mediterranean food plant extracts: Geographical differences. J. Physiol. Pharmacol. 2005, 56 (Suppl. S1), 115-124.

11. Stintzing, F.C.; Schieber, A.; Carle, R. Evaluation of colour properties and chemical quality parameters of cactus juices. Eur. Food Res. Technol. 2003, 216, 303-311.

12. Stintzing, F.C.; Schieber, A.; Carle, R. Phytochemical and nutritional significance of cactus pear. Eur. Food Res. Technol. 2001, 212, 396-407.

13. Galati, E.M.; Mondello, M.R.; Giuffrida, D.; Dugo, G.; Miceli, N.; Pergolizzi, S.; Taviano, M.F. Chemical characterization and biological effects of Sicilian Opuntia ficus indica (L.) mill. Fruit juice: Antioxidant and antiulcerogenic activity. J. Agric. Food Chem. 2003, 51, 4903-4908.

14. Galati, E.M.; Mondello, M.R.; Monforte, M.T.; Galluzzo, M.; Miceli, N.; Tripodo, M.M. Effect of Opuntia ficus-indica (L.) Mill. cladodes in the wound-healing process. J. Prof. Assoc. Cactus Dev. 2003, 5, 1-16.

15. Tesoriere, L.; Allegra, M.; Butera, D.; Livrea, M.A. Absorption, excretion, and distribution of dietary antioxidant betalains in LDLs: Potential health effects of betalains in humans. Am. J. Clin. Nutr. 2004, 80, 941-945.

16. Zou, D.-M.; Brewer, M.; Garcia, F.; Feugang, J.M.; Wang, J.; Zang, R.; Liu, H.; Zou, C. Cactus pear: a natural product in cancer chemoprevention. Nutr. J. 2005, 4, 25.

17. Dok-Go, H.; Lee, K.H.; Kim, H.J.; Lee, E.H.; Lee, J.; Song, Y.S.; Lee, Y.-H.; Jin, C.; Lee, Y.S.; Cho, J. Neuroprotective effects of antioxidative flavonoids, quercetin, (+)-dihydroquercetin and quercetin 3-Methyl ether, isolated from Opuntia ficus-indica var. saboten. Brain Res. 2003, 965, $130-136$. 
18. Galati, E.M.; Mondello, M.R.; Lauriano, E.R.; Taviano, M.F.; Galluzzo, M.; Miceli, N. Opuntia ficus indica (L.) Mill. fruit juice protects liver from carbon tetrachloride-induced injury. Phytother. Res. 2005, 19, 796-800.

19. Sreekanth, D.; Arunasree, M.K.; Roy, K.R.; Chandramohan Reddy, T.; Reddy, G.V.; Reddanna, P. Betanin a betacyanin pigment purified from fruits of Opuntia ficus-indica induces apoptosis in human chronic myeloid leukemia Cell line-K562. Phytomedicine 2007, 14, 739-746.

20. De Leo, M.; Abreu, M.B.D.; Pawlowska, A.M.; Cioni, P.L.; Braca, A. Profiling the chemical content of Opuntia ficus-indica flowers by HPLC-PDA-ESI-MS and GC/EIMS analyses. Phytochem. Lett. 2010, 3, 48-52.

21. Ramadan, M.F.; Mörsel, J.-T. Oil cactus pear (Opuntia ficus-indica L.). Food Chem. 2003, 82, 339-345.

22. Lee, J.-C.; Kim, H.-R.; Kim, J.; Jang, Y.-S. Antioxidant property of an ethanol extract of the stem of Opuntia ficus-indica var. saboten. J. Agric. Food Chem. 2002, 50, 6490-6496.

23. Stintzing, F.C.; Carle, R. Cactus stems (Opuntia spp.): A review on their chemistry, technology, and uses. Mol. Nutr. Food Res. 2005, 49, 175-194.

24. Laughton, M.J.; Evans, P.J.; Moroney, M.A.; Hoult, J.R.; Halliwell, B. Inhibition of mammalian 5-lipoxygenase and cyclo-oxygenase by flavonoids and phenolic dietary additives. Relationship to antioxidant activity and to iron ion-reducing ability. Biochem. Pharmacol. 1991, 42, 1673-1681.

25. Ahmed, M.S.; Tanbouly, N.D.E.; Islam, W.T.; Sleem, A.A.; Senousy, A.S.E. Antiinflammatory flavonoids from Opuntia dillenii (Ker-Gawl) Haw. flowers growing in Egypt. Phytother. Res. 2005, 19, 807-809.

26. Ammar, I.; Ennouri, M.; Khemakhem, B.; Yangui, T.; Attia, H. Variation in chemical composition and biological activities of two species of Opuntia flowers at four stages of flowering. Ind. Crop. Prod. 2012, 37, 34-40.

27. Clark, W.D.; Brown, G.K.; Mays, R.L. Flower flavonoids of Opuntia subgenus Cylindropuntia. Phytochemistry 1980, 19, 2042-2043.

28. Fernández-López, J.A.; Almela, L.; Obón, J.M.; Castellar, R. Determination of Antioxidant Constituents in Cactus Pear Fruits. Plant Food Hum. Nutr. 2010, 65, 253-259.

29. Bensadón, S.; Hervert-Hernández, D.; Sáyago-Ayerdi, S.G.; Goñi, I. By-Products of Opuntia ficus-indica as a Source of Antioxidant Dietary Fiber. Plant Food Hum. Nutr. 2010, 65, 210-216.

30. Moussa-Ayoub, T.E.; El-Samahy, S.K.; Kroh, L.W.; Rohn, S. Identification and quantification of flavonol aglycons in cactus pear (Opuntia ficus indica) fruit using a commercial pectinase and cellulase preparation. Food Chem. 2011, 124, 1177-1184.

31. Salim, N.; Abdelwaheb, C.; Rabah, C.; Ahcene, B. Chemical composition of Opuntia ficus-indica (L.) fruit. Afr. J. Biotechnol. 2009, 8, 1623-1624.

32. Tesoriere, L.; Fazzari, M.; Allegra, M.; Livrea, M.A. Biothiols, Taurine, and Lipid-Soluble Antioxidants in the Edible Pulp of Sicilian Cactus Pear (Opuntia ficus-indica) Fruits and Changes of Bioactive Juice Components upon Industrial Processing. J. Agric. Food Chem. 2005, 53, 7851-7855.

33. Chougui, N.; Tamendjari, A.; Hamidj, W.; Hallal, S.; Barras, A.; Richard, T.; Larbat, R. Oil composition and characterisation of phenolic compounds of Opuntia ficus-indica seeds. Food Chem. 2013, 139, 796-803. 
34. Jorge, A.J.; de La Garza, T.H.; Alejandro, Z.C.; Ruth, B.C.; Noé, A.C. The optimization of phenolic compounds extraction from cactus pear (Opuntia ficus-indica) skin in a reflux system using response surface methodology. Asian Pac. J. Trop. Biomed. 2013, 3, 436-442.

35. Gallegos-Infante, J.-A.; Rocha-Guzman, N.-E.; González-Laredo, R.-F.; Reynoso-Camacho, R.; Medina-Torres, L.; Cervantes-Cardozo, V. Effect of air flow rate on the polyphenols content and antioxidant capacity of convective dried cactus pear cladodes (Opuntia ficus indica). Int. J. Food Sci. Nutr. 2009, 60, 80-87.

36. Ginestra, G.; Parker, M.L.; Bennett, R.N.; Robertson, J.; Mandalari, G.; Narbad, A.; Lo Curto, R.B.; Bisignano, G.; Faulds, C.B.; Waldron, K.W. Anatomical, Chemical, and Biochemical Characterization of Cladodes from Prickly Pear [Opuntia ficus-indica (L.) Mill.]. J. Agric. Food Chem. 2009, 57, 10323-10330.

37. Guevara-Figueroa, T.; Jiménez-Islas, H.; Reyes-Escogido, M.L.; Mortensen, A.G.; Laursen, B.B.; Lin, L.-W.; de León-Rodríguez, A.; Fomsgaard, I.S.; Barba de la Rosa, A.P. Proximate composition, phenolic acids, and flavonoids characterization of commercial and wild nopal (Opuntia spp.). J. Food Compos. Anal. 2010, 23, 525-532.

38. Khatabi, O.; Hanine, H.; Elothmani, D.; Hasib, A. Extraction and determination of polyphenols and betalain pigments in the Moroccan Prickly pear fruits (Opuntia ficus indica). Arab. J. Chem. 2013, doi:10.1016/j.arabjc.2011.04.001.

39. Khan, N.S.; Ahmad, A.; Hadi, S.M. Anti-oxidant, pro-oxidant properties of tannic acid and its binding to DNA. Chem. Biol. Interact. 2000, 125, 177-189.

40. Yen, G.-C.; Duh, P.-D.; Tsai, H.-L. Antioxidant and pro-oxidant properties of ascorbic acid and gallic acid. Food Chem. 2002, 79, 307-313.

41. You, B.R.; Park, W.H. Gallic acid-induced lung cancer cell death is related to glutathione depletion as well as reactive oxygen species increase. Toxicol. In Vitro 2010, 24, 1356-1362.

42. Li, R.; Guo, M.; Zhang, G.; Xu, X.; Li, Q. Nicotiflorin reduces cerebral ischemic damage and upregulates endothelial nitric oxide synthase in primarily cultured rat cerebral blood vessel endothelial cells. J. Ethnopharmacol. 2006, 107, 143-150.

43. Nakayama, M.; Aihara, M.; Chen, Y.-N.; Araie, M.; Tomita-Yokotani, K.; Iwashina, T. Neuroprotective effects of flavonoids on hypoxia-, glutamate-, and oxidative stress-induced retinal ganglion cell death. Mol. Vis. 2011, 17, 1784.

44. Huang, J.-L.; Fu, S.-T.; Jiang, Y.-Y.; Cao, Y.-B.; Guo, M.-L.; Wang, Y.; Xu, Z. Protective effects of Nicotiflorin on reducing memory dysfunction, energy metabolism failure and oxidative stress in multi-infarct dementia model rats. Pharmacol. Biochem. Behav. 2007, 86, 741-748.

45. Kim, J.-E.; Lee, D.-E.; Lee, K.W.; Son, J.E.; Seo, S.K.; Li, J.; Jung, S.K.; Heo, Y.-S.; Mottamal, M.; Bode, A.M.; et al. Isorhamnetin Suppresses Skin Cancer through Direct Inhibition of MEK1 and PI3-K. Cancer Prev. Res. 2011, 4, 582-591.

46. Zhang, N.; Pei, F.; Wei, H.; Zhang, T.; Yang, C.; Ma, G.; Yang, C. Isorhamnetin protects rat ventricular myocytes from ischemia and reperfusion injury. Exp. Toxicol. Pathol. 2011, 63, 33-38.

47. Kim, B.; Choi, Y.-E.; Kim, H.-S. Eruca sativa and its Flavonoid Components, Quercetin and Isorhamnetin, Improve Skin Barrier Function by Activation of Peroxisome Proliferator-Activated Receptor (PPAR)- $\alpha$ and Suppression of Inflammatory Cytokines. Phytother. Res. 2014, doi:10.1002/ptr.5138. 
48. Lee, J.; Jung, E.; Lee, J.; Kim, S.; Huh, S.; Kim, Y.; Kim, Y.; Byun, S.Y.; Kim, Y.-S.; Park, D. Isorhamnetin represses adipogenesis in 3T3-L1 cells. Obesity 2009, 17, 226-232.

49. Ramachandran, L.; Manu, K.A.; Shanmugam, M.K.; Li, F.; Siveen, K.S.; Vali, S.; Kapoor, S.; Abbasi, T.; Surana, R.; Smoot, D.T.; et al. Isorhamnetin inhibits proliferation and invasion and induces apoptosis through the modulation of peroxisome proliferator-activated receptor $\gamma$ activation pathway in gastric cancer. J. Biol. Chem. 2012, 287, 38028-38040.

50. Abidi, S.; Ben Salem, H.; Vasta, V.; Priolo, A. Supplementation with barley or spineless cactus (Opuntia ficus indica f. inermis) cladodes on digestion, growth and intramuscular fatty acid composition in sheep and goats receiving oaten hay. Small Rumin. Res. 2009, 87, 9-16.

51. Charouf, Z.; Guillaume, D. Phenols and Polyphenols from Argania spinosa. Am. J. Food Technol. 2007, 2, 679-683.

52. Ramadan, M.F.; Moersel, J.-T. Lipid profile of prickly pear pulp fractions. J. Food Agric. Environ. 2003, 1, 66-70.

53. Ennouri, M.; Evelyne, B.; Laurence, M.; Hamadi, A. Fatty acid composition and rheological behaviour of prickly pear seed oils. Food Chem. 2005, 93, 431-437.

54. Marfil, R.; Cabrera-Vique, C.; Gimenez, R.; Bouzas, P.R.; Martinez, O.; Sanchez, J.A. Metal content and physicochemical parameters used as quality criteria in virgin argan oil: Influence of the extraction method. J. Agric. Food Chem. 2008, 56, 7279-7284.

55. Ollivier, D.; Artaud, J.; Pinatel, C.; Durbec, J.P.; Guerere, M. Triacylglycerol and fatty acid compositions of French virgin olive oils. Characterization by chemometrics. J. Agric. Food Chem. 2003, 51, 5723-5731.

56. Rubio, M.; Alvarez-Ortí, M.; Alvarruiz, A.S.; Fernández, E.; Pardo, J.E. Characterization of Oil Obtained from Grape Seeds Collected during Berry Development. J. Agric. Food Chem. 2009, 57, 2812-2815.

57. Ayorinde, F.O.; Garvin, K.; Saeed, K. Determination of the fatty acid composition of saponified vegetable oils using matrix-assisted laser desorption/ionization time-of-flight mass spectrometry. Rapid Commun. Mass Spectrom. 2000, 14, 608-615.

58. Karoui, I.J.; Wannes, W.A.; Marzouk, B. Refined corn oil aromatization by Citrus aurantium peel essential oil. Ind. Crop. Prod. 2010, 32, 202-207.

59. Filip, S.; Hribar, J.; Vidrih, R. Influence of natural antioxidants on the formation of trans-fatty-acid isomers during heat treatment of sunflower oil. Eur. J. Lipid Sci. Technol. 2011, 113, 224-230.

60. Ramadan, M.F.; Mörsel, J.-T. Recovered lipids from prickly pear [Opuntia ficus-indica (L.) Mill] peel: A good source of polyunsaturated fatty acids, natural antioxidant vitamins and sterols. Food Chem. 2003, 83, 447-456.

61. Soel, S.M.; Choi, O.S.; Bang, M.H.; Yoon Park, J.H.; Kim, W.K. Influence of conjugated linoleic acid isomers on the metastasis of colon cancer cells in vitro and in vivo. J. Nutr. Biochem. 2007, $18,650-657$.

62. Cayuela, J.A.; Rada, M.; del Carmen Pérez-Camino, M.; Benaissa, M.; Abdelaziz, E.; Guinda, Á. Characterization of artisanally and semiautomatically extracted argan oils from Morocco. Eur. J. Lipid Sci. Technol. 2008, 110, 1159-1166. 
63. Khallouki, F.; Younos, C.; Soulimani, R.; Oster, T.; Charrouf, Z.; Spiegelhalder, B.; Bartsch, H.; Owen, R.W. Consumption of argan oil (Morocco) with its unique profile of fatty acids, tocopherols, squalene, sterols and phenolic compounds should confer valuable cancer chemopreventive effects. Eur. J. Cancer Prev. 2003, 12, 67-75.

64. Piga, A. Cactus pear: A fruit of nutraceutical and functional importance. J. Prof. Assoc. Cactus Dev. 2004, 6, 9-22.

65. Feugang, J.M.; Konarski, P.; Zou, D.; Stintzing, F.C.; Zou, C. Nutritional and medicinal use of Cactus pear (Opuntia spp.) cladodes and fruits. Front. Biosci. 2006, 11, 2574-2589.

66. Sawaya, W.N.; Khan, P. Chemical Characterization of Prickly Pear Seed Oil, Opuntia ficus-indica. J. Food Sci. 1982, 47, 2060-2061.

67. Gharby, S.; Harhar, H.; Guillaume, D.; Haddad, A.; Matthäus, B.; Charrouf, Z. Oxidative stability of edible argan oil: A two-year study. LWT-Food Sci. Technol. 2011, 44, 1-8.

68. El Kossori, R.L.; Villaume, C.; El Boustani, E.; Sauvaire, Y.; Méjean, L. Composition of pulp, skin and seeds of prickly pears fruit (Opuntia ficus indica sp.). Plant Food Hum. Nutr. 1998, 52, 263-270.

69. Sawaya, W.N.; Khatchadourian, H.A.; Safi, W.M.; Al-Muhammad, H. Chemical characterization of prickly pear pulp, Opuntia ficus-indica, and the manufacturing of prickly pear jam. Int. J. Food Sci. Technol. 1983, 18, 183-193.

70. Medina, E.M.D.; Rodríguez, E.M.R.; Romero, C.D. Chemical characterization of Opuntia dillenii and Opuntia ficus indica fruits. Food Chem. 2007, 103, 38-45.

71. Ayadi, M.A.; Abdelmaksoud, W.; Ennouri, M.; Attia, H. Cladodes from Opuntia ficus indica as a source of dietary fiber: Effect on dough characteristics and cake making. Ind. Crop. Prod. 2009, $30,40-47$.

72. Trachtenberg, S.; Mayer, A.M. Mucilage Cells, Calcium Oxalate Crystals and Soluble Calcium in Opuntia ficus-indica. Ann. Bot. 1982, 50, 549-557.

73. Sawaya, W.N.; Khalil, J.K.; Al-Mohammad, M.M. Nutritive value of prickly pear seeds, Opuntia ficus-indica. Plant Food Hum. Nutr. 1983, 33, 91-97.

74. Contreras-Padilla, M.; Pérez-Torrero, E.; Hernández-Urbiola, M.I.; Hernández-Quevedo, G.; del Real, A.; Rivera-Muñoz, E.M.; Rodríguez-García, M.E. Evaluation of oxalates and calcium in nopal pads (Opuntia ficus-indica var. redonda) at different maturity stages. J. Food Compos. Anal. 2011, 24, 38-43.

75. Nassar, A.G. Chemical composition and functional properties of prickly pear (Opuntia ficus indica) seeds flour and protein concentrate. World J. Dairy Food Sci. 2008, 3, 11-16.

76. Uchoa, A.F.; Souza, P.A.S.; Zarate, R.M.L.; Gomes-Filho, E.; Campos, F.A.P. Isolation and characterization of a reserve protein from the seeds of Opuntia ficus-indica (Cactaceae). Braz. J. Med. Biol. Res. 1998, 31, 757-761.

77. Zito, P.; Sajeva, M.; Bruno, M.; Rosselli, S.; Maggio, A.; Senatore, F. Essential oils composition of two Sicilian cultivars of Opuntia ficus-indica (L.) Mill. (Cactaceae) fruits (prickly pear). Nat. Prod. Res. 2013, 27, 1305-1314.

78. Castellanos-Santiago, E.; Yahia, E.M. Identification and Quantification of Betalains from the Fruits of 10 Mexican Prickly Pear Cultivars by High-Performance Liquid Chromatography and Electrospray Ionization Mass Spectrometry. J. Agric. Food Chem. 2008, 56, 5758-5764. 
79. Fernández-López, J.A.; Castellar, R.; Obón, J.M.; Almela, L. Screening and mass-spectral confirmation of betalains in cactus pears. Chromatographia 2002, 56, 591-595.

80. Fernández-López, J.A.; Giménez, P.J.; Angosto, J.M.; Moreno, J.I. A process of recovery of a natural yellow colourant from opuntia fruits. Food Technol. Biotechnol. 2012, 50, 246-251.

81. Strack, D.; Vogt, T.; Schliemann, W. Recent advances in betalain research. Phytochemistry 2003, 62, 247-269.

82. Stintzing, F.C.; Herbach, K.M.; Mosshammer, M.R.; Carle, R.; Yi, W.; Sellappan, S.; Akoh, C.C.; Bunch, R.; Felker, P. Color, betalain pattern, and antioxidant properties of cactus pear (Opuntia spp.) clones. J. Agric. Food Chem. 2005, 53, 442-451.

83. Ahmad, A.; Davies, J.; Randall, S.; Skinner, G.R.B. Antiviral properties of extract of Opuntia streptacantha. Antivir. Res. 1996, 30, 75-85.

84. Kaur, M.; Kaur, A.; Sharma, R. Pharmacological actions of Opuntia ficus indica: A Review. J. Appl. Pharm. Sci. 2012, 2, 1.

85. Lee, J.-A.; Jung, B.-G.; Kim, T.-H.; Lee, S.-G.; Park, Y.-S.; Lee, B.-J. Dietary feeding of Opuntia humifusa inhibits UVB radiation-induced carcinogenesis by reducing inflammation and proliferation in hairless mouse model. Photochem. Photobiol. 2013, 89, 1208-1215.

86. Lee, J.-A.; Jung, B.-G.; Lee, B.-J. Inhibitory effects of Opuntia humifusa on 7, 12-dimethylbenz[a]anthracene and 12-O-tetradecanoylphorbol-13- acetate induced two-stage skin carcinogenesis. Asian Pac. J. Cancer Prev. 2012, 13, 4655-4660.

87. Tomczyk, M.; Zovko-Koncić, M.; Chrostek, L. Phytotherapy of alcoholism. Nat. Prod. Commun. 2012, 7, 273-280.

88. Tesoriere, L.; Attanzio, A.; Allegra, M.; Gentile, C.; Livrea, M.A. Indicaxanthin inhibits

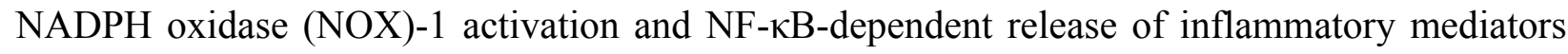
and prevents the increase of epithelial permeability in IL-1 $\beta$-exposed Caco-2 cells. Br. J. Nutr. 2014, 111, 415-423.

89. Panico, A.M.; Cardile, V.; Garufi, F.; Puglia, C.; Bonina, F.; Ronsisvalle, S. Effect of hyaluronic acid and polysaccharides from Opuntia ficus indica (L.) cladodes on the metabolism of human chondrocyte cultures. J. Ethnopharmacol. 2007, 111, 315-321.

90. Gentile, C.; Tesoriere, L.; Allegra, M.; Livrea, M.A.; D’Alessio, P. Antioxidant betalains from cactus pear (Opuntia ficus-indica) inhibit endothelial ICAM-1 expression. Ann. N. Y. Acad. Sci. 2004, 1028, 481-486.

91. Lee, M.H.; Kim, J.Y.; Yoon, J.H.; Lim, H.J.; Kim, T.H.; Jin, C.; Kwak, W.-J.; Han, C.-K.; Ryu, J.-H. Inhibition of nitric oxide synthase expression in activated microglia and peroxynitrite scavenging activity by Opuntia ficus indica var. saboten. Phytother. Res. 2006, 20, 742-747.

92. Kim, J.-H.; Park, S.-M.; Ha, H.-J.; Moon, C.-J.; Shin, T.-K.; Kim, J.-M.; Lee, N.-H.; Kim, H.-C.; Jang, K.-J.; Wie, M.-B. Opuntia ficus-indica attenuates neuronal injury in in vitro and in vivo models of cerebral ischemia. J. Ethnopharmacol. 2006, 104, 257-262.

93. Allegra, M.; Ianaro, A.; Tersigni, M.; Panza, E.; Tesoriere, L.; Livrea, M.A. Indicaxanthin from cactus pear fruit exerts anti-inflammatory effects in carrageenin-induced rat pleurisy. J. Nutr. 2014, 144, 185-192. 
94. Morán-Ramos, S.; Avila-Nava, A.; Tovar, A.R.; Pedraza-Chaverri, J.; López-Romero, P.; Torres, N. Opuntia ficus indica (nopal) attenuates hepatic steatosis and oxidative stress in obese Zucker (fa/fa) rats. J. Nutr. 2012, 142, 1956-1963.

95. Castillo, S.L.; Heredia, N.; Contreras, J.F.; García, S. Extracts of edible and medicinal plants in inhibition of growth, adherence, and cytotoxin production of Campylobacter jejuni and Campylobacter coli. J. Food Sci. 2011, 76, M421-M426.

96. Sánchez, E.; García, S.; Heredia, N. Extracts of Edible and Medicinal Plants Damage Membranes of Vibrio cholerae. Appl. Environ. Microbiol. 2010, 76, 6888-6894.

97. Vázquez-Ramírez, R.; Olguín-Martínez, M.; Kubli-Garfias, C.; Hernández-Muñoz, R. Reversing gastric mucosal alterations during ethanol-induced chronic gastritis in rats by oral administration of Opuntia ficus-indica mucilage. World J. Gastroenterol. 2006, 12, 4318-4324.

98. Wiese, J.; McPherson, S.; Odden, M.C.; Shlipak, M.G. Effect of Opuntia ficus indica on symptoms of the alcohol hangover. Arch. Intern. Med. 2004, 164, 1334-1340.

99. Kleiner, O.; Cohen, Z.; Mares, A.J. Low colonic obstruction due to Opuntia ficus indica seeds: The aftermath of enjoying delicious cactus fruits. Acta Paediatr. 2002, 91, 606-607.

100. Oh, P.-S.; Lim, K.-T. Glycoprotein $(90 \mathrm{kDa})$ isolated from Opuntia ficus-indica var. saboten MAKINO lowers plasma lipid level through scavenging of intracellular radicals in Triton WR-1339-induced mice. Biol. Pharm. Bull. 2006, 29, 1391-1396.

101. Deldicque, L.; van Proeyen, K.; Ramaekers, M.; Pischel, I.; Sievers, H.; Hespel, P. Additive insulinogenic action of Opuntia ficus-indica cladode and fruit skin extract and leucine after exercise in healthy males. J. Int. Soc. Sports Nutr. 2013, 10, 45.

102. Godard, M.P.; Ewing, B.A.; Pischel, I.; Ziegler, A.; Benedek, B.; Feistel, B. Acute blood glucose lowering effects and long-term safety of OpunDia supplementation in pre-diabetic males and females. J. Ethnopharmacol. 2010, 130, 631-634.

103. Butterweck, V.; Semlin, L.; Feistel, B.; Pischel, I.; Bauer, K.; Verspohl, E.J. Comparative evaluation of two different Opuntia ficus-indica extracts for blood sugar lowering effects in rats. Phytother. Res. 2011, 25, 370-375.

104. Van Proeyen, K.; Ramaekers, M.; Pischel, I.; Hespel, P. Opuntia ficus-indica ingestion stimulates peripheral disposal of oral glucose before and after exercise in healthy men. Int. J. Sport Nutr. Exerc. Metab. 2012, 22, 284-291.

105. Alarcon-Aguilar, F.J.; Valdes-Arzate, A.; Xolalpa-Molina, S.; Banderas-Dorantes, T.; Jimenez-Estrada, M.; Hernandez-Galicia, E.; Roman-Ramos, R. Hypoglycemic activity of two polysaccharides isolated from Opuntia ficus-indica and O. streptacantha. Proc. West. Pharmacol. Soc. 2003, 46, 139-142.

106. Nuñez-López, M.A.; Paredes-López, O.; Reynoso-Camacho, R. Functional and Hypoglycemic Properties of Nopal Cladodes (O. ficus-indica) at Different Maturity Stages Using in Vitro and in Vivo Tests. J. Agric. Food Chem. 2013, 61, 10981-10986.

107. Park, E.H.; Kahng, J.H.; Lee, S.H.; Shin, K.H. An anti-inflammatory principle from cactus. Fitoterapia 2001, 72, 288-290.

108. Allegra, M.; Furtmuller, P.G.; Jantschko, W.; Zederbauer, M.; Tesoriere, L.; Livrea, M.A.; Obinger, C. Mechanism of interaction of betanin and indicaxanthin with human myeloperoxidase and hypochlorous acid. Biochem. Biophys. Res. Commun. 2005, 332, 837-844. 
109. Tesoriere, L.; Butera, D.; Pintaudi, A.M.; Allegra, M.; Livrea, M.A. Supplementation with cactus pear (Opuntia ficus-indica) fruit decreases oxidative stress in healthy humans: A comparative study with vitamin C. Am. J. Clin. Nutr. 2004, 80, 391-395.

110. Ennouri, M.; Ammar, I.; Khemakhem, B.; Attia, H. Chemical Composition and Antibacterial Activity of Opuntia Ficus-Indica F. Inermis (Cactus Pear) Flowers. J. Med. Food 2014, 17, 908-914.

111. Yasmeen, R.; Hashmi, A.S.; Anjum, A.A.; Saeed, S.; Muhammad, K. Antibacterial activity of indigenous herbal extracts against urease producing bacteria. J. Anim. Plant. Sci. 2012, 22, 416-419.

(C) 2014 by the authors; licensee MDPI, Basel, Switzerland. This article is an open access article distributed under the terms and conditions of the Creative Commons Attribution license (http://creativecommons.org/licenses/by/4.0/). 